\title{
Arthroscopic Removal of Metallic Suture Anchors Placed after Bankart Repair
}

\author{
Olcay Guler ${ }^{*}$, Mehmet Isyar ${ }^{2}$, Selami Cakmak², Melih Malkoc ${ }^{3}$, Halis Cerci ${ }^{4}$, \\ Mahir Mahirogullari ${ }^{5}$
}

${ }^{1}$ School of Medicine, Department of Orthopaedics and Traumatology, Istanbul Istinye University, Istanbul, Turkey

${ }^{2}$ Department of Orthopaedics and Traumatology, Acıbadem Kadıkoy Hospital, Istanbul, Turkey

${ }^{3}$ School of Medicine, Department of Orthopaedics and Traumatology, Istanbul Medipol University, Istanbul, Turkey

${ }^{4}$ Department of Orthopaedic and Traumatology, Nisa Hospital, Istanbul, Turkey

${ }^{5}$ Memorial Health Group, Department of Orthopaedics and Traumatology, Istanbul, Turkey

Email: *olcayguler77@gmail.com,misyar2003@yahoo.com, selamicakmak@gmail.com,memalkoc@yahoo.com,

doblili@hotmail.com, mahirogullari@yahoo.com

How to cite this paper: Guler, O., Isyar, M., Cakmak, S., Malkoc, M., Cerci, H. and Mahirogullari, M. (2019) Arthroscopic Removal of Metallic Suture Anchors Placed after Bankart Repair. International Journal of Clinical Medicine, 10, 543-552.

https://doi.org/10.4236/ijcm.2019.1010044

Received: September 20, 2019

Accepted: October 20, 2019

Published: October 23, 2019

Copyright $\odot 2019$ by author(s) and Scientific Research Publishing Inc. This work is licensed under the Creative Commons Attribution International License (CC BY 4.0).

http://creativecommons.org/licenses/by/4.0/

\begin{abstract}
Purpose: The aim of this study was to present our surgical outcomes in patients who underwent arthroscopic removal of poorly positioned and/or proud metallic suture anchors applied during or after Bankart repair. Methods: A total of 14 patients who underwent open or arthroscopic Bankart repair with an initial presentation of traumatic shoulder instability between January 2010 and January 2017 and admitted to our center with complaints due to poorly positioned and/or proud metallic suture anchors were enrolled. Pre- and intraoperative findings, surgical outcomes and complications were reviewed. Diagnosis of proud or poorly positioned suture anchors was established using magnetic resonance imaging (MRI) of shoulder in five cases, and with shoulder arthroscopy in nine patients. Outcomes were measured by the use of the CONSTANT score and American Shoulder and Elbow Society (ASES) score. Results: Eleven male and three female patients with an average age of $29.21 \pm 5.78$ (range, 20 to 42 ) were enrolled in the present study. Revision Bankart repair was performed arthroscopically in all patients. The mean follow-up period was 40.4 months, ranging from 18 to 64 months. The preoperative Constant and ASES scores were $68.43 \pm 7.05$ and $38.3 \pm 19.4$, respectively. Postoperatively, the scores were $89.64 \pm 5.39$ and $89.07 \pm 3.89$, respectively $(\mathrm{p}<0.01)$. Conclusion: To conclude, arthroscopy may yield an effective surgical option for removal of poorly positioned and/or proud metallic suture anchors after Bankart repair. However, further clinical reports on larger series are warranted to document the efficacy of this procedure in selected cases.
\end{abstract}




\section{Keywords}

Arthroscopy, Shoulder, Surgery, Bankart Repair, Complication

\section{Introduction}

Arthroscopy of shoulder joint is been used commonly for diagnosis and treatment of glenohumeral joint pathologies. Intra-articular implants introduced in conjunction with arthroscopy have provided successful outcomes in terms of soft tissue reconstruction [1].

Arthroscopic Bankart repair surgery using suture anchors has become the most common surgery for management of post-traumatic anteroinferior instability of the shoulder joint. It mostly provides satisfactory outcomes; however, recurrence rates of instability may be more than expected rising up to rates of $35 \%-40 \%$ especially in patients younger than 25 years of age. Moreover, the results seem to worsen during long-term follow-up [2] [3]. Since patients suffering from failed Bankart repair are generally young and active people, necessity for revision stabilization surgery often arises. In this purpose, open Bankart operation, revision arthroscopic Bankart operation or glenoid rim reconstruction with bone grafting can be used for restoration of joint stability [4] [5]. Nevertheless, the optimal technique for revision has not been well defined yet in the literature.

In parallel to the popularization of shoulder arthroscopy, there has been a remarkable increase in the frequency of complications associated with implants used for repair of rotator cuff or stabilization of shoulder joint. Suture anchors have been implemented frequently for fixation during soft tissue repair. However, poorly positioned suture anchors result in continuous pain, cartilage injury, restriction of motion and failure of reconstruction [6].

Male gender, young age, bony defects, hyperlaxity, and poor-quality joint capsule are among risk factors for failure of arthroscopic Bankart repair [7]. If 20\% - $30 \%$ of the glenoid width is eroded, failure is more likely and unrecognised glenoid or humeral bony defects constitute common reasons for recurrence after Bankart repair [8] [9]. The variety and combination or interaction of soft tissue and bony pathologies complicate the identification of the appropriate method for revision surgery.

Arthroscopic shoulder surgery has been popularized recently in accordance with improvement of understanding of the complex anatomy and functioning of shoulder joint. However, in case that complications occur, there is mostly a lack of consensus on the method of management. Lack of guidance necessitates clarification for selection of the most appropriate method in the management of complications. The current study was carried out to present our outcomes for arthroscopic removal of poorly positioned and/or proud metallic suture anchors placed during Bankart repair in 14 consecutive cases. 


\section{Patients and Methods}

\subsection{Study Design}

This retrospective study has been conducted in accordance with the principles of the Helsinki Declaration. Written informed consent was obtained from all subjects. Approval of local Institutional Review Board has been obtained priorly (February 2018).

A total of 14 patients who underwent open or arthroscopic Bankart repair with an initial presentation of traumatic shoulder instability between January 2010 and January 2017 and admitted to our center with complaints due to poorly positioned and/or proud metallic suture anchors were enrolled in our study. The data obtained from the patient records were information on the operative findings, surgical outcomes and complications.

Inclusion criteria: The criteria for inclusion were 1) patients over 18 years, 2) the presence of traumatic shoulder instability in the initial admission, 3) Bankart repair open or arthroscopic with use of either open or arthroscopic techniques, 4) surgery performed by the same surgeon (O.G.) or under his direction.

Exclusion criteria: Exclusion criteria were 1) patients under 18 years, 2) using anchors other than metallic suture anchors.

\subsection{Outcome Parameters}

Pre- and intraoperative findings, surgical outcomes and complications were reviewed. Diagnosis of proud or poorly positioned suture anchors was established using magnetic resonance imaging (MRI) of shoulder in five cases, and with shoulder arthroscopy in nine patients (Figure 1(a) and Figure 1(b)).

Patients were evaluated the day before surgery and at last follow-up. Constant scores, and American Shoulder and Elbow Surgeons (ASES) scores were compared.

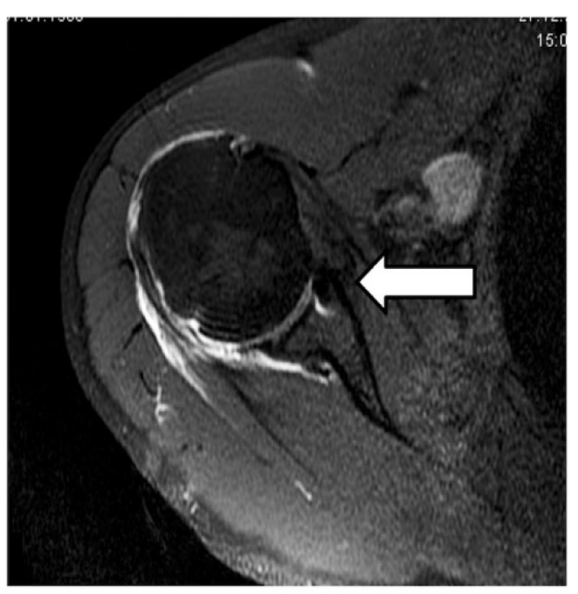

(a)

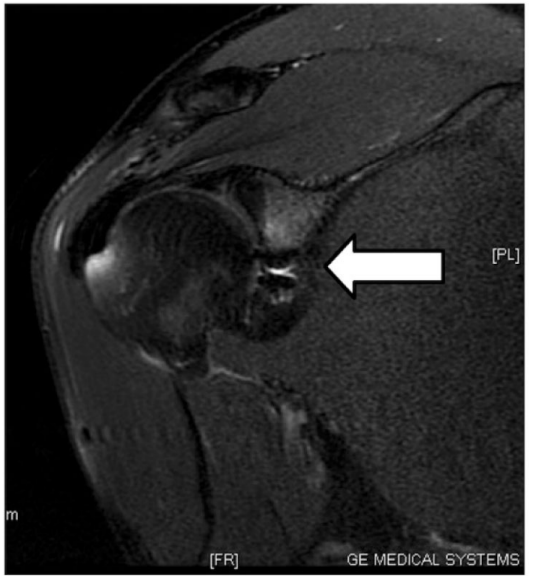

(b)

Figure 1. (a) and (b) Magnetic resonance views demonstrating poorly positioned metallic anchors resulting in stiffness and pain of the shoulder joint (white arrow). 


\subsection{Statistical Analyses}

Data were analyzed using the IBM Statistical Package for Social Sciences v21 (SPSS Inc., Chicago, IL, USA). Parametric tests were applied to data of normal distribution and non-parametric tests were applied to data of questionably normal distribution. The results for all items were expressed as mean $\pm \mathrm{SD}$, assessed within a $95 \%$ reliance and at a level of $\mathrm{p}<0.05$ significance.

\section{Results}

Demographic and initial surgical data of the patients are presented in Table 1. Eleven male and three female patients with an average age of $29.21 \pm 5.78$ (range, 20 to 42) were enrolled in the present study. The right side was affected in 9 (64.3\%) cases and the left side in $5(35.7 \%)$ cases. The dominant side was affected in 10 (71.4\%) cases. Initially, eleven cases had undergone primary arthroscopic Bankart repair, while three patients had been operated with open Bankart repair. Metallic suture anchors have been placed during primary surgery in thirteen patients and during revision surgery in one patient. Mean number of metallic suture anchors used in the initial surgery was $2.36 \pm 0.50$ (range, 2 to 3 ). The main complaint was pain in $9(64.3 \%)$ cases, metallic clicking sound in 8 (57.1\%) cases, recurrent dislocation in $5(35.7 \%)$ cases, and stiffness in $2(14.3 \%)$ cases. Mean duration of the complaints was $5.57 \pm 2.31$ (range, 2 to 9 ) months. Metallic suture anchors aided the confirmation of diagnosis by radiological methods in 5 cases; however, it must not be neglected that confirmation of diagnosis required arthroscopy in 9 cases.

Revision Bankart repair was performed arthroscopically in all patients. Findings of revision surgery are presented in Table 2. In all cases, arthroscopic removal of poorly positioned suture anchors could be accomplished successfully. Suture anchors were found to be extending from the cartilaginous surface of the shoulder joint. In the patient whose poor positioning of the anchor occurred during revision surgery, removal of anchor was carried out using screwdriver. In eight cases, expulsion of anchors by rotation was managed using acutenaculum after dissection from surrounding tissues. In two cases, the suture anchor was taken out after dilatation of its periphery with a $6.5 \mathrm{~mm}$ mosaic plastic cannula used for autologous osteochondral transfer system (Figure 2(a) and Figure 2(b)) [10]. Grafting was not performed since the bare area was beyond the ventral part of the joint. Eleven cases had undergone primary arthroscopic Bankart repair, while three patients had been operated with open Bankart repair and the average operation time was 5.5 (range, 2 to 9 ) months. The mean follow-up period was 40.4 months, ranging from 18 to 64 months.

The preoperative Constant and ASES scores were $68.43 \pm 7.05$ and $38.3 \pm 19.4$, respectively. Postoperatively, the scores were $89.64 \pm 5.39$ and $89.07 \pm 3.89$, respectively $(\mathrm{p}<0.01)$ (Table 3$)$.

\section{Discussion}

The aim of the present study was to present our results in arthroscopic 
Table 1. Demographic and initial surgical data of the patients.

\begin{tabular}{|c|c|c|c|c|c|c|c|c|c|}
\hline No & Gender & $\begin{array}{c}\text { Age } \\
\text { (years) }\end{array}$ & Dominancy & Side & $\begin{array}{c}\text { Previous } \\
\text { Surgical } \\
\text { Technique }\end{array}$ & $\begin{array}{l}\text { Number of metallic } \\
\text { anchors in the } \\
\text { initial surgery }\end{array}$ & Complaints & $\begin{array}{c}\text { Duration of } \\
\text { complaint } \\
\text { (month) }\end{array}$ & $\begin{array}{l}\text { Anchor } \\
\text { Problem }\end{array}$ \\
\hline 1 & Male & 20 & Dominant & $\mathrm{R}$ & Arthroscopic & 3 & $\begin{array}{c}\text { Pain } \\
\text { Stiffness }\end{array}$ & 2 & $\begin{array}{l}\text { Proud } \\
\text { anchor }\end{array}$ \\
\hline 2 & Female & 42 & Non-dominant & $\mathrm{L}$ & Arthroscopic & 2 & $\begin{array}{c}\text { Pain } \\
\text { Metallic } \\
\text { clicking sound }\end{array}$ & 8 & $\begin{array}{l}\text { Proud } \\
\text { anchor }\end{array}$ \\
\hline 3 & Male & 35 & Non-dominant & $\mathrm{R}$ & Arthroscopic & 3 & $\begin{array}{c}\text { Pain } \\
\text { Metallic } \\
\text { clicking sound }\end{array}$ & 9 & $\begin{array}{l}\text { Proud } \\
\text { anchor }\end{array}$ \\
\hline 4 & Female & 30 & Dominant & $\mathrm{R}$ & Arthroscopic & 2 & $\begin{array}{l}\text { Recurrent } \\
\text { dislocation }\end{array}$ & 4 & $\begin{array}{c}\text { Poorl } \\
\text { positioned } \\
\text { anchor }\end{array}$ \\
\hline 5 & Male & 24 & Dominant & $\mathrm{L}$ & Arthroscopic & 2 & $\begin{array}{l}\text { Recurrent } \\
\text { dislocation }\end{array}$ & 5 & $\begin{array}{l}\text { Poorly } \\
\text { positioned } \\
\text { anchor }\end{array}$ \\
\hline 6 & Male & 26 & Dominant & $\mathrm{R}$ & Open & 2 & $\begin{array}{c}\text { Pain } \\
\text { Metallic } \\
\text { clicking sound }\end{array}$ & 3 & $\begin{array}{l}\text { Proud } \\
\text { anchor }\end{array}$ \\
\hline 7 & Male & 28 & Dominant & $\mathrm{R}$ & Arthroscopic & 3 & $\begin{array}{c}\text { Pain } \\
\text { Metallic } \\
\text { clicking sound }\end{array}$ & 5 & $\begin{array}{l}\text { Proud } \\
\text { anchor }\end{array}$ \\
\hline 8 & Male & 30 & Non-dominant & $\mathrm{L}$ & Open & 2 & $\begin{array}{c}\text { Pain } \\
\text { Metallic } \\
\text { clicking sound }\end{array}$ & 6 & $\begin{array}{l}\text { Proud } \\
\text { anchor }\end{array}$ \\
\hline 9 & Female & 33 & Non-dominant & $\mathrm{L}$ & Arthroscopic & 2 & $\begin{array}{l}\text { Recurrent } \\
\text { dislocation }\end{array}$ & 7 & $\begin{array}{c}\text { Poorly } \\
\text { positioned } \\
\text { anchor }\end{array}$ \\
\hline 10 & Male & 31 & Dominant & $\mathrm{L}$ & Open & 2 & $\begin{array}{c}\text { Pain } \\
\text { Metallic } \\
\text { clicking sound }\end{array}$ & 8 & $\begin{array}{l}\text { Proud } \\
\text { anchor }\end{array}$ \\
\hline 11 & Male & 20 & Dominant & $\mathrm{R}$ & Arthroscopic & 2 & $\begin{array}{l}\text { Pain Metallic } \\
\text { clicking sound } \\
\text { Stiffness }\end{array}$ & 9 & $\begin{array}{l}\text { Proud } \\
\text { anchor }\end{array}$ \\
\hline 12 & Male & 30 & Dominant & $\mathrm{R}$ & Arthroscopic & 3 & $\begin{array}{l}\text { Recurrent } \\
\text { dislocation }\end{array}$ & 5 & $\begin{array}{c}\text { Poorly } \\
\text { positioned } \\
\text { anchor }\end{array}$ \\
\hline 13 & Male & 32 & Dominant & $\mathrm{R}$ & Arthroscopic & 3 & $\begin{array}{c}\text { Pain } \\
\text { Metallic } \\
\text { clicking sound }\end{array}$ & 4 & $\begin{array}{l}\text { Proud } \\
\text { anchor }\end{array}$ \\
\hline 14 & Male & 28 & Dominant & $\mathrm{R}$ & Arthroscopic & 2 & $\begin{array}{l}\text { Recurrent } \\
\text { dislocation }\end{array}$ & 3 & $\begin{array}{l}\text { Poorly } \\
\text { positioned } \\
\text { anchor }\end{array}$ \\
\hline
\end{tabular}

management of poorly positioned and/or proud metallic suture anchors applied during or after Bankart repair. Our results indicate that arthroscopy seems to be a safe and effective alternative in the surgical management of these patients. 
Table 2. Findings of revision surgery.

\begin{tabular}{|c|c|c|c|c|c|c|c|}
\hline No & $\begin{array}{l}\text { Anchor's position } \\
\text { in the glenoid }\end{array}$ & $\begin{array}{l}\text { Anchor's } \\
\text { position } \\
\text { (o'clock) }\end{array}$ & $\begin{array}{l}\text { Surgical } \\
\text { procedure } \\
\text { in revision }\end{array}$ & $\begin{array}{l}\text { Method of } \\
\text { anchor } \\
\text { removal }\end{array}$ & $\begin{array}{l}\text { Number of } \\
\text { anchors } \\
\text { removed }\end{array}$ & $\begin{array}{c}\text { Presence of } \\
\text { intraarticular } \\
\text { chondral destruction } \\
\text { Humerus/glenoid }\end{array}$ & $\begin{array}{l}\text { Follow-up } \\
\text { (months) }\end{array}$ \\
\hline 1 & Glenoid rim & 3 & Removal of anchor & Screwdriver & 1 & No & 25 \\
\hline 2 & Glenoid $5 \mathrm{~mm}$ medial & 3 & Removal of anchor & Screwdriver & 1 & $\begin{array}{c}\text { Yes } \\
\text { Humerus }\end{array}$ & 56 \\
\hline 3 & Glenoid $10 \mathrm{~mm}$ medial & $3-5$ & Removal of anchor & $\begin{array}{c}\text { Autologous } \\
\text { osteochondral } \\
\text { transfer system }\end{array}$ & 2 & $\begin{array}{c}\text { Yes } \\
\text { Glenoid }\end{array}$ & 60 \\
\hline 4 & Glenoid rim & 4 & $\begin{array}{c}\text { Removal of anchor } \\
\text { Revision Bankart repair }\end{array}$ & Screwdriver & 1 & $\begin{array}{c}\text { Yes } \\
\text { Humerus }\end{array}$ & 34 \\
\hline 5 & Glenoid rim & 4 & $\begin{array}{c}\text { Removal of anchor } \\
\text { Revision Bankart repair }\end{array}$ & Screwdriver & 1 & $\begin{array}{c}\text { Yes } \\
\text { Humerus }\end{array}$ & 48 \\
\hline 6 & Glenoid $8 \mathrm{~mm}$ medial & 3 & Removal of anchor & Screwdriver & 1 & $\begin{array}{c}\text { Yes } \\
\text { Humerus }\end{array}$ & 24 \\
\hline 7 & Glenoid $10 \mathrm{~mm}$ medial & 3 & Removal of anchor & Screwdriver & 1 & $\begin{array}{c}\text { Yes } \\
\text { Glenoid }\end{array}$ & 18 \\
\hline 8 & Glenoid rim & 3 & Removal of anchor & Screwdriver & 1 & $\begin{array}{c}\text { Yes } \\
\text { Humerus }\end{array}$ & 64 \\
\hline 9 & Glenoid rim & 4 & $\begin{array}{c}\text { Removal of anchor } \\
\text { Revision Bankart repair }\end{array}$ & $\begin{array}{c}\text { Autologous } \\
\text { osteochondral } \\
\text { transfer system }\end{array}$ & 1 & $\begin{array}{c}\text { Yes } \\
\text { Humerus }\end{array}$ & 48 \\
\hline 10 & Glenoid $5 \mathrm{~mm}$ medial & 3 & Removal of anchor & Screwdriver & 1 & No & 32 \\
\hline 11 & Glenoid $5 \mathrm{~mm}$ medial & 3 & Removal of anchor & Screwdriver & 1 & No & 36 \\
\hline 12 & Glenoid rim & 4 & Removal of anchor & $\begin{array}{c}\text { Autologous } \\
\text { osteochondral } \\
\text { transfer system }\end{array}$ & 1 & $\begin{array}{c}\text { Yes } \\
\text { Humerus }\end{array}$ & 25 \\
\hline 13 & Glenoid rim & 3 & Removal of anchor & Screwdriver & 1 & $\begin{array}{c}\text { Yes } \\
\text { Humerus }\end{array}$ & 56 \\
\hline 14 & Glenoid $10 \mathrm{~mm}$ medial & 5 & Removal of anchor & $\begin{array}{c}\text { Autologous } \\
\text { osteochondral } \\
\text { transfer system }\end{array}$ & 1 & $\begin{array}{c}\text { Yes } \\
\text { Humerus }\end{array}$ & 60 \\
\hline
\end{tabular}

Table 3. Clinical scores in preoperative and postoperative periods.

\begin{tabular}{cccc}
\hline & $\begin{array}{c}\text { Preoperatively } \\
\text { mean } \pm \text { SD (range) }\end{array}$ & $\begin{array}{c}\text { Postoperatively } \\
\text { mean } \pm \text { SD (range) }\end{array}$ & $\boldsymbol{P \text { value }}$ \\
\hline Constant score & $68.43 \pm 7.05(59-83)$ & $89.64 \pm 5.39(82-98)$ & $<0.01$ \\
ASES score & $64.00 \pm 7.14(55-81)$ & $89.07 \pm 3.89(86-98)$ & $<0.01$ \\
\hline
\end{tabular}

ASES $=$ American Shoulder and Elbow Society.

Reported rates of complications vary between 4.6\% - 10.6\% [11]. Careful selection of patients, understanding and adherence of indications, good knowledge of anatomy and appropriate patient positioning are useful measures that may aid in reduction of complication rates [12]. In case complications occur, there is 


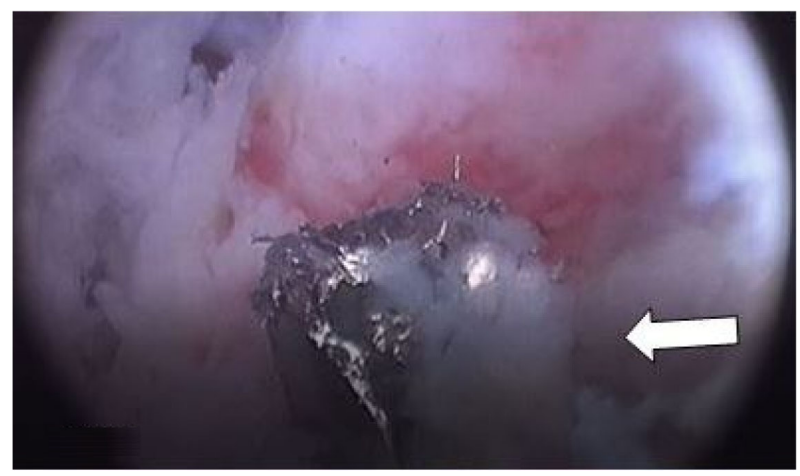

(a)

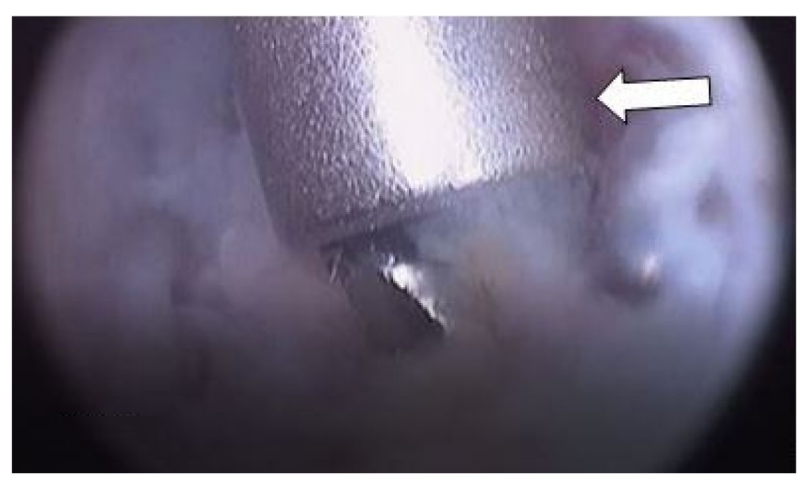

(b)

Figure 2. (a) Arthroscopic appearance of poorly positioned suture anchor (white arrow); (b) Arthroscopic appearance of peripheral dilatation of poorly positioned suture anchor with autologous osteochondral transfer system canula (white arrow).

mostly a lack of consensus on the method of management. Lack of guidance necessitates clarification for selection of the most appropriate method in the management of complications. Choice of metal or radiolucent implants can determine the follow-up of the position of implants in the postoperative period [11] [12]. In our series, metal anchors aided the confirmation of diagnosis by radiological methods in 3 cases, but it must not be neglected that confirmation of diagnosis required arthroscopy in 8 cases.

Zuckerman et al. reviewed 37 cases with glenohumeral joint complications after open surgery and revealed that ten patients had erosive changes in the humeral head or the glenoid cavity associated with the incorrect placement of the fixture [13]. Kaar et al. studied 8 cases with complications after open surgery in which metals utureanchors were used and showed that 3 cases developed serious joint damage caused by a loose or exposed metal anchor [14]. Ejnisman et al. studied eight cases with complications due to the use of anchors in open and arthroscopic surgeries and showed that all cases had chondral injuries of the humeral head and $80 \%$ had chondral injuries of the glenoid cavity [15]. Our study shows complications with the use of metal anchors. Of the 14 patients total, 11 had glenohumeral chondral damage in various grades.

Koss et al. observed a case in which there was increasing pain and crepitus a few weeks after open stabilization of a Bankart lesion [16]. The symptoms were 
more prominent in abduction and internal rotation of the arm. In our series, we found that the most common symptoms were pain and metallic clicking sound.

Rhee et al. reported performing the second surgery an average of 12 months after primary surgery [17]. Ejnisman et al. reported that only one (12.5\%) of the eight patients was revised in the first six weeks, the remainder were revised after three months [15]. The data in the literature regarding the time of the revision are contradictory. In our study, the time between the first and second surgeries was 5.5 months.

Even though recurrence after arthroscopic surgery is still a challenge, new technology and improved surgical practice have yielded better functional results with less morbidity. On the other hand, a meta-analysis by Lenters et al. have shown that arthroscopic suture techniques were linked with increased risks of recurrent instability and dislocation compared to open technique [18]. Despite this report, arthroscopic repair was found to provide better functional scores than open surgical methods [6]. It must be remembered that arthroscopy offers a better diagnostic ability, facility to repair all accompanying lesions, dimunition of likelihood of stiffness, shorter time of surgery and less postoperative pain compared to open technique. Technical errors such as poor positioning of the anchors can lead to failure of arthroscopic Bankart repair even in patients with appropriate indications [19]. In addition to poor positioning of the anchors, insufficient number of suture anchors or inappropriate depth of knotless anchors may be linked with recurrence [19]. Our case series denotes that poor positioning of suture anchors is not a rare entity that must be kept in mind while revisiting risk factors for failure of arthroscopic surgery. Identification of factors underlying failure accurately is mandatory for establishment of correct management strategy.

Regarding clinical results, we observed that the arthroscopic Bankart repair showed a significant improvement in outcome scores. The Constant and ASES scores increased from $68.43 \pm 7.05$ and $38.3 \pm 19.4$, respectively, in the preoperative evaluation to $89.64 \pm 5.39$ and $89.07 \pm 3.89$, respectively at the postoperative follow-up ( $\mathrm{p}<0.01)$.

Limitation of our study includes the retrospective design and relatively small number of patients in our series. This is high-volume surgeon operating in a high-volume hospital, and studies have shown that these 2 factors contribute to improved clinical outcomes. It is likely that surgeon and hospital volume affected both the technical and operational efficiency and lowered our complication rates. As a result, relatively small number of patients was included in our series. In addition, some details of history and factors that may influence the outcome may not be completely documented. Due to these restrictions, associations should be interpreted with caution. Further prospective, controlled trials on larger series are necessary for making more precise interpretations.

\section{Conclusion}

In conclusion, arthroscopic surgery may yield an effective surgical option for 
removal of poorly positioned and/or proud metallic suture anchors applied during or after Bankart repair. However, further clinical reports on larger series are warranted to document the efficacy of this procedure in selected cases.

\section{Acknowledgements}

Special thanks to Harun Mutlu, MD because of his contributions for verbal presentation in $8^{\text {th }}$ Turkish Shoulder and Elbow Surgery Congress.

\section{Financial}

No financial support was received for this paper.

\section{Conflicts of Interest}

The authors declare no competing interests.

\section{References}

[1] Flinkkilä, T. and Sirniö, K. (2015) Open Latarjet Procedure for Failed Arthroscopic Bankart Repair. Orthopaedics \& Traumatology. Surgery \& Research, 101, 35-38. https://doi.org/10.1016/j.otsr.2014.11.005

[2] Flinkkilä, T., Hyvönen, P., Ohtonen, P. and Leppilahti, J. (2010) Arthroscopic Bankart Repair: Results and Risk Factors of Recurrence of Instability. Knee Surgery, Sports Traumatology, Arthroscopy, 18, 1752-1758.

https://doi.org/10.1007/s00167-010-1105-5

[3] Voos, J.E., Livermore, R.W., Feeley, B.T., Altchek, D.W., Williams, R.J., Warren, R.F., et al. (2010) Prospective Evaluation of Arthroscopic Bankart Repairs for Anterior Instability. The American Journal of Sports Medicine, 38, 302-307. https://doi.org/10.1177/0363546509348049

[4] Cho, N.S., Woong, J., Lee, B.G. and Rhee, Y.G. (2009) Revision Open Bankart Surgery after Arthroscopic Repair for Traumatic Anterior Shoulder Instability. The American Journal of Sports Medicine, 37, 2158-2164. https://doi.org/10.1177/0363546509339015

[5] Abouali, J.A.K., Hatzatoni, K., Holtby, R., Veilette, C. and Theodoropoulos, J. (2013) Revision Arthroscopic Bankart Repair. Arthroscopy, 29, 1572-1578. https://doi.org/10.1016/j.arthro.2013.04.017

[6] Noud, P.H. and Esch, J. (2013) Complications of Arthroscopic Shoulder Surgery. Sports Medicine and Arthroscopy Review, 21, 89-96. https://doi.org/10.1097/JSA.0b013e31829006f0

[7] Randelli, P., Ragone, V., Carminati, S. and Cabiza, P. (2012) Risk Factors for Recurrence after Bankart Repair. A Systematic Review. Knee Surgery, Sports Traumatology, Arthroscopy, 20, 2129-2138. https://doi.org/10.1007/s00167-012-2140-1

[8] Sommaire, C., Penz, C., Clavert, P., Klouche, S., Hardy, P. and Kempf, J.F. (2012) Recurrence after Arthroscopic Bankart Repair: Is Quantitative Radiological Analysis of Bone Loss of Any Predictive Value. Orthopaedics \& Traumatology: Surgery \& Research, 98, 514-519. https://doi.org/10.1016/j.otsr.2012.03.015

[9] Burkhart, S.S. and De Beer, J.F. (2000) Traumatic Glenohumeral Bone Defects and Their Relationship to Failure of Arthroscopic Bankart Repairs: Significance of the Inverted Pear Glenoid and the Humeral Engaging Hill-Sachs Lesion. Arthroscopy, 16, 677-694. https://doi.org/10.1053/jars.2000.17715 
[10] Grutter, P.W., McFarland, E.G., Zikria, B.A., Dai, Z. and Petersen, S.A. (2010) Techniques for Suture Anchor Removal in Shoulder Surgery. The American Journal of Sports Medicine, 38, 1706-1710. https://doi.org/10.1177/0363546510372794

[11] Marecek, G.S. and Saltzman, M.D. (2010) Complications in Shoulder Arthroscopy. Orthopedics, 33, 492-497. https://doi.org/10.3928/01477447-20100526-15

[12] Moen, T.C., Rudolph, G.H., Caswell, K., Espinoza, C., Burkhead, W.Z. and Krishnan, S.G. (2014) Complications of Shoulder Arthroscopy. The Journal of the American Academy of Orthopaedic Surgeons, 22, 410-419. https://doi.org/10.5435/JAAOS-22-07-410

[13] Zuckerman, J.D. and Matsen, F.A. 3rd (1984) Complications about the Glenohumeral Joint Related to the Use Screws and Staples. The Journal of Bone and Joint Surgery. American Volume, 66, 175-180. https://doi.org/10.2106/00004623-198466020-00003

[14] Kaar, T.K., Schenck, R.C., Wirth, M.A. and Rockwood, C.A. (2001) Complications of Metallic Suture Anchors in Shoulder Surgery: A Report of 8 Cases. Arthroscopy, 17, 31-37. https://doi.org/10.1053/jars.2001.18246

[15] Ejnisman, B., Andreoli, C.V., Pochini, A.C., Monteiro, G.C., Feloppa, F. and Cohen, M. (2006) Artropatiaglenoumeralpós-tratamento de lesõeslabiais com implantesmetálicos. Revista Brasileira de Ortopedia, 41, 167-172.

[16] Koss, S., Richmond, J.C. and Woodward, J.R. (1997) Two to Five-Year Follow up of Arthroscopic Bankart Reconstruction Using a Suture Anchor Technique. The American Journal of Sports Medicine, 26, 809-812. https://doi.org/10.1177/036354659702500613

[17] Rhee, Y.G., Lee, D.H., Chun, I.H. and Bae, S.C. (2004) Glenohumeral Arthropathy after Arthroscopic Anterior Shoulder Stabilization. Arthroscopy, 20, 402-406. https://doi.org/10.1016/j.arthro.2004.01.027

[18] Lenters, T.R., Franta, A.K., Wolf, F.M., Leopold, S.S. and Matsen, F.A. 3rd (2007) Arthroscopic Compared with Open Repairs for Recurrent Anterior Shoulder Instability. A Systematic Review and Meta-Analysis of the Literature. The Journal of Bone and Joint Surgery. American Volume, 89, 244-254. https://doi.org/10.2106/00004623-200702000-00003

[19] Law, B.K., Yung, P.S., Ho, E.P., Chang, J.J. and Chan, K.M. (2008) The Surgical Outcome of Immediate Arthroscopic Bankart Repair for First Time Anterior Shoulder Dislocation in Young Active Patients. Knee Surgery, Sports Traumatology, Arthroscopy, 16, 188-193. https://doi.org/10.1007/s00167-007-0453-2 